\title{
Responses to the COVID-19 Pandemic among the Amish of Northern Indiana
}

\author{
Victor E. Stoltzfus \\ President Emeritus \\ Goshen College \\ vicstoltzfus@gmail.com
}

\begin{abstract}
Retired sociologist and college administrator Victor Stoltzfus reflects on a series of meetings in 2020 between leaders of the large Elkhart-LaGrange Amish settlement and state and local public health officials seeking to mitigate the spread of COVID-19. Multiple sources of information, some of questionable provenance, worked against the reception and application of public health directives, as did the decentralized polity of the Amish church. The authority of medical science is not absolute in Amish circles and the Amish relationship with government includes elements of both obedience and distrust. The generally positive reputation the Amish enjoy in the wider public may be at risk as some non-Amish neighbors are dismayed by half-hearted Amish efforts to slow the spread of the pandemic. Stoltzfus concludes by noting the inconsistent mitigation practices on the part of the surrounding non-Amish population in northern Indiana.
\end{abstract}

Submitted December 18, 2020; accepted January 22, 2021; published March 24, 2021

https://doi.org/10.18061/jpac.v1i2.8099

Keywords: Amish, COVID-19, public health

$\mathrm{D}$ uring summer and fall 2020, in cooperation with Indiana health officials and later with the Centers for Disease Control and Prevention, I helped facilitate several meetings that involved more than 18 Amish leaders from the large Elkhart-LaGrange Amish settlement. In these gatherings, public health and Amish participants asked questions, expressed concerns, and exchanged information about the COVID-19 pandemic. Vigorous discussions resulted and there were expressions of Amish appreciation for this outreach. I also had personal phone conversations with three Amish leaders. What follows also relies on anecdotes that have been cross-checked with various Amish and non-Amish informants. I acknowledge the limitations of anecdotal evidence and the risk of over-generalizing from a few cases. It would be impossible to draw a random sample and do survey research in this population on a controversial issue. You need to have a trusting relationship even to elicit stories.

Nearly 60,000 Amish people live in Indiana, with a concentration of about 33,000 in Elkhart, LaGrange, Noble, Kosciusko, and Marshall Counties in northern Indiana. ${ }^{1}$ With large families,

\footnotetext{
1 “Amish Population, 2020," Young Center for Anabaptist and Pietist Studies, Elizabethtown College. http:/groups.etown.edu/amishstudies/statistics/population-2020/; and "Twelve Largest Amish Settlements, 2020,” http://groups.etown.edu/amishstudies/statistics/twelve-largest-settlements-2020/.
} 
averaging six children, their age distribution skews younger than the general population. This gives them an advantage as a population in terms of COVID, since the virus is more lethal to older people.

The challenge of this pandemic did not happen in a medical vacuum. In The Amish, Donald Kraybill and his coauthors describe four systems of health care that the Amish employ in combination: ${ }^{2}$

1. folk medicine, including an array of food supplements or herbal concoctions, a self-trained Amish counselor for mental health,

2. an alternative system, illustrated by everything from local homeopathic treatment to using Mexican doctors for cancer or complex surgery,

3. the standard system, for regular hospital knee surgery or a mental hospital for emotional health, and

4. the church-community system, which includes financial and emotional support from church resources. The family system alone provides more than 200 people supporting the average individual.

The authors point out that the use of these systems varies widely among the Amish. With this variety in health practices before the pandemic, we should not be surprised to find varied responses to COVID now. As with pre-COVID health practices, there are similarities as well as important differences across the Amish population as they confront the pandemic.

We who are not Amish are sometimes overly influenced by the parts of Amish culture that we can see and hear. Beards, buggies, and bonnets look much the same. Cemeteries look the same, facility with the Pennsylvania Dutch language is similar. Therefore, many imagine that it follows that all Amish would have the same responses to the pandemic. This is emphatically not the case.

The use of masks is uneven, but it is not common in Amish gatherings. Some even violate the regulations of stores that require customer to wear masks. The northern Indiana Amish settlements are distinctive nationally for the large number of men who work in non-Amish industries, mostly in firms manufacturing recreational vehicles. Some of these factories in recent months are requiring employees to wear masks. Amish people in our community tell stories of masks being hard on people with asthma or cutting off oxygen and causing a person to fall from a ladder. Due to the December 2020 spike in infections in Elkhart County, the Goshen City Council considered fining people without masks, but yielded to public pressure and backed off.

As of this writing, social distancing is not being observed in Amish church services, weddings, funerals, or informal gatherings. For a few weeks, in the early days of COVID, Governor Eric Holcomb shut down gatherings and businesses. Amish people complied and there were almost no infections. When restrictions were relaxed in the next stage of reopening, Amish socializing returned to normal, though several Amish leaders later said, "We went overboard." All gatherings resumed without social distancing, including weddings and funerals of 200 to 600 people. Many

\footnotetext{
${ }^{2}$ Donald B. Kraybill, Karen M. Johnson-Weiner, and Steven M. Nolt, The Amish (Baltimore: Johns Hopkins University Press, 2013), 339-345.
} 
became infected, a few died, but caution was diminished. Numerous folks had a few days or weeks of illness but recovered without hospitalization. Mothers who came to birthing centers spurned health advice by nurse midwives. We should also say that, even as infections spike in December, expressions of caution from many state officials have been less than robust, allowing those who disregard public health advice to feel that they are acting appropriately. As of this writing, inrestaurant dining is permitted and bars are open in Indiana, including in Elkhart County.

Multiple sources of information are another factor in the variation in responses. The hundreds of so-called "English" outsiders who are hired to drive Amish pass along Fox News perspectives and a lot of colorful misinformation. For example, there is a rumor that hospitals get paid for virus patients and thus have an incentive to exaggerate infection numbers. We hear that all lethal motorcycle accidents are automatically called virus-related. We hear that the vaccine will contain a computer chip, which will allow the government to track all movements. We hear that when testing happens, the test puts the virus in one's body. When free testing was offered to LaGrange and Elkhart County Amish by our county health department, I heard Amish leaders say that they did not think anyone would show up.

Another source of variety in the Amish response to COVID is the lack of a unified message from Amish bishops, who are not themselves at the same place in understanding the threat to their people. In several meetings with Amish leaders, I also sensed that they felt weak in their ability to influence their people on this issue. By now, both attitudes and behaviors in the laity have had time to solidify, and many Amish people are resisting public health recommendations. Some of them do read about the virus in the newspapers in our region, and a few follow the rates of infection in local counties. They are all aware that elderly people are more at risk of dying from this disease.

Informal conversation among family and trusted friends is the single most important source of information in Amish culture. There are some who see the virus as just another flu, and others who are scared. In one case, an Amish woman was fearful of having church at her house, but she was reluctant to share her fears with the bishop. As she was getting ready to host church, the bishop had a close relative who got extremely sick. He called off church for that Sunday, and she was grateful. There are other instances of cancelling church when the bishop knows that many are sick. The editor of Die Blatt, an Amish biweekly newspaper, published a message urging masks and social distancing by Dr. Kristina Box, the top medical official in Indiana. I learned that the editor got a lot of criticism for publishing her advice.

Some COVID cautions are half-hearted. Several Amish informants have said that some gatherings are smaller than usual. But they sit rather close and they sing. Even if the numbers are smaller, the chances for transmission are still excellent. At least one of the bishops urges obedience to masking rules upon entering stores, so as not to give offense to English neighbors. One of the districts has been putting disinfectant in the water used for the religious ritual of foot washing that accompanies communion. An Amish informant told me that the ritual of shaking hands with everyone at a funeral has been suspended in at least one church district. Another Amish friend knows of people who self-quarantine and people who take care not to be spreaders. 
The theory of herd immunity, as misinterpreted by the Amish, has many supporters. In my conversations, I heard a lot of people say, "We have herd immunity" or "It just has to take its course." They correctly believe that if a large proportion of a community has been infected, the whole community will be protected. What they fail to mention is that it is not clear that COVID infection will give lasting immunity. What they also fail to take into account is that long before the nation reaches a threshold of 70 percent or more infected and achieves herd immunity, the hospital systems will be overwhelmed. This is the current reality across the nation. Some health experts also claim that it would cost the nation millions of deaths to get to herd immunity through unchecked infection alone.

We have noted that it is important to see the Amish response to COVID in light of health attitudes and behaviors before the pandemic. It is also important to see how this challenge fits into long-established religious beliefs and practices. Kraybill and his coauthors in The Amish define Amish religious beliefs today as rooted in the 1632 Dordrecht Confession of Faith, which specifies adult baptism, separation from the world, and nonviolence. Amish also use horse-drawn transportation and speak a German dialect. ${ }^{3}$ In Europe and from time to time in America, the Amish have been persecuted or pressured. Half of the songs in their songbook are martyr songs. This history teaches them that the world cannot be fully trusted. Their schools do not teach elementary science. When the local Amish communities did shut down worship services for nearly two months in response to Governor Holcomb's early dictate, they drew on a tradition of principled respect for government. They often quote Hebrews 13:17: "Obey them that have the rule over you." This obedience is deep in the tradition.

However, the authority of science, not woven into their time-tested folk wisdom, is less salient. Until that has time to become tradition, the Amish are as individualistic as the rest of us in their response to the pandemic. They prefer to work out their own solutions. Only extreme problems such as addictions to alcohol or sex, or flagrant spouse or child abuse, will cause the more progressive Amish to go outside the community for help.

A few anecdotes shed light on how Amish religious consciousness affects the current crisis of pandemic. A young Amish woman, when asked about not having a mask, pointed to her white prayer head covering and said, "This is my mask." A few say that COVID is an act of God and no human responses are called for. Others dispute this and do take some precautions. An elderly Amish man told me, "We are living in the end times. We might have to suffer to hold fast to the faith." A doctor serving many Amish observed to me that any death is viewed as God's will. Such a view does not lead to a robust inquiry about how untimely deaths can be prevented so that there are fewer funerals.

The Amish in our community enjoyed a lot of admiration for their way of life prior to COVID. Their crime rates are low. Their dependence on taxpayer programs for food, housing, and so forth is nonexistent. (I write in late 2020 when an interruption in several government programs resulted in an estimated one out of four children in the larger society having insufficient food.) Our thriving

\footnotetext{
${ }^{3}$ Kraybill, Johnson-Weiner, and Nolt, The Amish, 12-21.
} 
recreation vehicle factories are vitally dependent upon Amish labor. Their apprenticeship programs within the family and community produce highly skilled people in construction, farming, and a myriad of small businesses. Their farms produce hundreds of thousands of chickens and ducks. Yes, there is a growing number of Amish millionaires. In a time of extreme individualism in the larger society, the strong family and community life excite admiration. The Amish are admired for their very modest use of fossil fuels in a time of climate change.

This good reputation is now at risk. Their lack of response to clear public health messages is not only a threat to their own community, but also to the larger society. This produces fear, resentment, and some anger. I quote a local health professional: "I am incredibly disappointed in the Amish community. They are reckless and self-centered." Another health provider said, "They feel entitled." That is, they do not feel it necessary to conform to people outside their own community. A friend of mine said, "I am disgusted by the Amish response to COVID." Another used the word disappointment. A third friend hesitates to engage Amish friends in conversation because of the health risk involved in doing so. A businessman with a motel in Florida said that a few Amish are coming and so English customers fear staying in a place with Amish in nearby rooms. A local Amish toy shop owner has a sign in his shop: "No masks allowed." A physician who has treated Amish for decades caught the virus and nearly died. Saved by a ventilator, he is back at work, still dedicated to save all who need help.

In light of the educational and religious roots of Amish life, one can understand how the current challenge of a pandemic results in varied responses. Until Amish bishops have members meetings and produce a church-supported expression of conscience, church district by church district, the Amish are on their own as individuals. They draw from their cultural tradition, scary rumors, the medical advice they choose to accept from doctors, and the beliefs of others in their community. Because this challenge has come too rapidly to blend into the common culture, the usually vigorous resource of a strong community in the cause of preventative health behaviors is weak or nonexistent. To the medical professionals, the Amish rejection of medical truth seems to be a threat to their own community and to the wider non-Amish community.

Now it is time to take a glance at the English, or non-Amish, response to COVID. Many have resisted the efforts of the governor and his top health adviser, even though I assume that many of these resisters have studied high school or college biology. In November of 2020 when I called attention to English resistance to public health measures in conversation with Dr. Box, Indiana's state health commissioner, she agreed, saying, "Oh, the stories I could tell!"

I am a citizen of a town that has many residents who conscientiously follow public health measures. They wear masks, especially indoors in public settings. Some are so careful that they only meet their own children and grandchildren outdoors, distanced and with masks. I know of persons who this year observed Christmas alone out of health concerns.

We also have a minority of angry protestors who loudly oppose "the mask Nazis." Sometimes those who oppose public health measures have overwhelmed public meetings. The pressure on our public health officials has been unrelenting. At the federal level, this past Christmas season (2020) 
featured one high-ranking government official planning a final party in a space that was too small for social distancing. Invitations to 900 resulted in only 70 planning to come. A second party was cancelled when the cabinet official himself got infected. And this is all in the context of so many infections that the hospitals of the nation are reaching or exceeding capacity. This is in the tragic context of deaths per day in December 2020 in the United States often exceeding the tragic loss of life on $9 / 11$.

To summarize, in northern Indiana we live with an Amish community with varied responses to a pandemic. Some are heeding public health messages. Many others are significantly influenced by centuries of distrust of science, lethal persecution in Europe, and some negative experiences with governmental power in the United States. This is reflected among those who have chosen to resist public health messages.

And we live amid a non-Amish community where public health messages have become politicized and divisive. This results in varied responses on a continuum similar to that of the Amish. In such a time as this, our doctors, nurses, and public health officials must indeed be regarded as heroes. I believe they would gladly swap public acclaim for a greater openness to their public health message. One put it this way: "Let's all look out for each other." 